\title{
Referees for 2012
}

\section{J. Angelo Corlett}

(C) Springer Science+Business Media B.V. 2012

The Editor-in-Chief wishes to extend gratitude to the following philosophers, along with members of the Editorial Board, for their excellent service to The Journal of Ethics during the past year:

William H. Baumer

Jerome Bickenbach

William James Booth

Tad Brennan

Claudia F. Card

Bradford Cokelet

Omar Dahbour

Melissa Seymour Fahmy

Ernesto V. Garcia

Joshua Gert

Kevin W. Gibson

Daniel Guevara

Ish Haji

Terry Horgan

Patricia Kazan

David Merli

John E. Roemer

Peter Vranas 